\title{
ANOTASI BIBLIOGRAFI
}

\section{Penggunaan Aplikasi Pembelajaran, Sejarah Pendidikan Di Indonesia, Profesi Keguruan}

Oleh

\section{Rizal Putra Yohannur}

Email : $1910111310002 @$ mhs.ulm.ac.id

Program studi pendidikaan sejarah fakultas keguruan dan

Ilmu pendidikan

Universitas Lambung Mangkurat

\section{Banjarmasin}

Susanto, H., \& Akmal, H. (2018). Efektivitas Penggunaan Aplikasi Pembelajaran Berbasis Mobile Smartphone Sebagai Media Pengenalan Sejarah Lokal Masa Revolusi Fisik Di Kalimantan Selatan Pada Siswa Sekolah Menengah Atas. HISTORIA: Jurnal Program Studi Pendidikannn Sejarah, 6(2), 197-206.

Artikel ini mengkaji tentang penggunaan aplikasi pembelajaraan berbasis mobile smartphone sebagaii media pengenalan sejarah lokal masa revolusi fisik yang ada di kalimantan selatan pada siswa sekolah menengah atas. Jadi pada penggunaan teknologi aplikasi pembelajaran semakin berkembang dalam kehidupan masyarakat karena adanya fasilitas tersebut yang dianggap sebagai fasilitas untuk membantu pekerjaan dan sehingga pembelajaran menjadi sangat efektif. Pada artikel ini menjelaskan sejarah merupakan aktivitas manusia di masa lalu yang tidak dapat dilihat secara langsung di masa sekarang. Jadi sebagai pendidik harus memberikan contoh nyata atau bisa saja langsung terjun ke tempat benda bersejarah yang berada di museum agar siswa dapat langsung memahami benda-benda bersejarah secara langsung. Pada artikel ini memberi kita poin-poin penting dalam penggunaan aplikasi pembelajaran berbasis mobile smartphone. Pada umumnya aplikasi pembelajaran dapat diakses melalui berbaga perangkat terutama bisa menggunakan laptop dan menggunakan mobile smartphone.

Syaharudin., \& Susanto, H. (2019). Sejarah Pendidikan Indonesia Era Pra Kolonialisme Nusantara Sampai Reformasi.

Pada buku ini terdapat 5 Bab yang membahas tentang, pendidikan do nusantara pada masa pra kolonialisme, pendidikan di nusantara pada masa kolonialisme, pendidikan indonesia pada masa orde lama. Pendidikan indonesia pada masa orde baru, dan pendidikan di indonesia pada masa reformasi. Pada buku ini menjelaskan tentang pendidikan indonesia pada tahun 1965 bisa dikatakan banyak sekali dipengaruhi oleh sistem pendidikan belanda. Praktek selepas penjajahan menekankan pengembangan jiwa patriotisme. Buku ini juga menjelaskan kurikulum petama kali dikeluarkan pada tahun 1968 yang merupakan tonggak awal pendidikan pada masa orde baru. Kelahiran kurikulum pada tahun 1968 ini masih bersifat politis.kurikulum tahun 1968 ini lebih menekankan untuk sekolah dasar. Pada masa ini siswa hanya berperan sebagai pribadi yang pasif, dengan hanya menghapal menghapal teori-teori yang ada tanpa ada pengaplikasian dari teori. 
Susanto, H. (2020). Profesi Keguruan

Buku ini menjelaskan guru mempuyai peranan yang amat strategis dan urgent dalam keseluruhan upaya pendidikan. Profesi guru ini merupakan profesi yang dapat menentukan masa depan bangsa ini. Pada buku ini guru sebagai pendidik yang profesional, dengan tugas utama mendidik, mengajar, membimbing, mengarahkan, melatih, menilai, dan mengevaluasi peserta didik pada usia dini jalur pendidikan formal, pedidikan dasar, dan juga pendidikan menengah. Buku ini menjelaskan dengan sangat jelas tentang apa itu profesi guru dan sangat mudah untuk di pahami buku ini memiliki 3 bab yang membahas tentang konsep profesi keguruan, sikap profesional keguruan dan kompetensi guru, dan pengembangan profesi guru

\section{Simpulan Konseptual Anotasi Bibliografi}

Proses kegiatan belajar mengajar di sekolah menengah atas sudah berjalan dengan dengan sangat baik. Fasilitas yang ada di setiap sekoalah menengah atas sudah dimanfaatkan dengan sebaik-baiknya oleh para guru untuk menyampaikan materi pembelajaran khususnya pemebelajaran mata pelajaran sejarah.

Setiap pendidikan pada dasarnya berhak mendapatkan pendidikan dan pengajaran. Pendidikan merupakan kebutuhan yang sangat penting bagi manusia. Manusia dapat mencapai tujuan kemampuan diberbagai bidang yang pada akhirnya dapat menempatkan seseorang pada derajat yag lebih baik. Oleh karena itu, pendidikan menjadi satu kebutuhan yang cukup penting dalam mengalami perubahan dan kemajuan di zaman modern ini.

Profesi keguruan memiliki citra yang baik didalam lingkungan masyarakat profesi guru ini dapat menunjukan kepada masyarakat bahwa guru layak menjadi panutan dan teladan bagi masyarakat di sekelilinginya. 